\title{
The Sentence Imposed Versus the Statutory Maximum: Repairing the Armed Career Criminal Act
}

Desmond Akil Smith was a twenty-two-year-old star offensive lineman on the Clemson University football team. During his junior year, undercover police officers caught him in a drug bust. In a two-week period, Smith sold marijuana three times to undercover operatives within a half-mile of the Clemson campus. ${ }^{1}$ He pleaded guilty to three counts of distributing drugs near a school. ${ }^{2}$ Though each of those counts carried a maximum of ten years in prison under South Carolina law, ${ }^{3}$ the judge sentenced Smith only to two years' probation. ${ }^{4}$ But despite his mild sentence, Smith had committed at least three "serious drug offenses" for purposes of the Federal Armed Career Criminal Act (ACCA) because ACCA-predicate offenses are based upon statutory maximum sentences. ${ }^{5}$ If he were to buy and register a firearm at any point in his life, he would become an "armed career criminal" under the ACCA and would face a mandatory minimum of fifteen years in prison. ${ }^{6}$

In contrast to Smith, serious offenders often are not covered by the ACCA. Mark Regopoulos, for example, was the "accused ringleader of a high-level marijuana operation that was based out of a downtown ... pizza shop" near

1. Kimathi Lewis \& Ken Tysiac, Star Clemson Players Face Felony Drug Counts, STATE (Columbia, S.C.), Dec. 5, 2001, at A1.

2. Ken Tysiac, Zachery Receives Probation, State (Columbia, S.C.), June 28, 2002, at C2. Smith also pleaded guilty to three counts of marijuana distribution. Id.

3. See S.C. CODE ANN. \$44-53-445 (2002).

4. Tysiac, supra note 2.

5. 18 U.S.C. $\$ 924(e)(2000)$.

6. Id. $\$ 924(e)(1)$. 
Penn State. ${ }^{7}$ As part of a drug bust, Regopoulos was arrested and charged with a dozen counts of drug-related crimes. He pleaded guilty to three felony counts of delivering marijuana. ${ }^{8}$ Each count carried a maximum of five years in prison. ${ }^{9}$. Regopoulos received 9 to 23.5 months. ${ }^{10}$ Yet because the maximum sentence was five years rather than ten for each conviction, none of Regopoulos's offenses constitute ACCA predicates; there is no chance that he would find himself subject to the ACCA's fifteen-year mandatory minimum at some point in the future.

This Comment argues that Congress should repair this defect by amending the Armed Career Criminal Act to define the predicate "serious drug offenses" and "violent felonies" by the sentence actually imposed rather than the maximum an offender could have received. " Making this adjustment would ensure that our justice system imposes the most serious consequences on the most culpable offenders, align the ACCA with deportation standards in immigration law and with the Federal Sentencing Guidelines, and reduce the practical difficulties that are built into the present system.

\section{BACKGROUND OF THE ARMED CAREER CRIMINAL ACT}

Congress enacted the ACCA in 1984 to address the growing threat to society posed by armed, repeat criminals. The ACCA created a "new federal crime" designed to keep "the most dangerous, frequent and hardened offenders" off the streets. ${ }^{12}$ The Act mandates a term of fifteen years to life for a felon in possession of a firearm with three or more prior convictions for serious crimes. ${ }^{13}$ The fifteen-year term was designed to "incapacitate the armed career

7. Margaret Miceli, Gopper's Owner Takes Plea Deal, Dally CollegIAN (State College, Pa.), Jan. 31, 2008, at 1, available at http://www.collegian.psu.edu/archive/2008/o1/31/ goppers_owner_takes_plea_deal.aspx.

8. Id.

9. 35 PA. CONS. Stat. ANN. $\$ 780-113(f)(2)$ (West 2003).

10. See Miceli, supra note 7.

11. This Comment does not suggest defining ACCA-predicate offenses by the prison time the defendant actually served. A variety of issues unrelated to a defendant's culpability influence the amount of time a defendant actually spends in jail. Many states, for example, have responded to prison overcrowding by instituting controversial early release programs. See, e.g., Cal. STATE SHERIfFs' ASs'N, JAIL OVERCROWDING REPORT (2006), http://www.calsheriffs.org/legislative_jail_overcrowding.htm.

12. S. REP. NO. $97-585$, at 5 (1982).

13. 18 U.S.C. $\$ 924(e)(1)(2000)$. 
criminal for the rest of the normal time span of his career which usually starts at about age 15 and continues to about age $30 . " 14$

The ACCA's fifteen-year minimum is triggered if the defendant has three or more prior convictions for drug distribution offenses or violent felonies. Those so-called "predicate" crimes are defined in part by the longest prison term a defendant could receive for committing the crime, regardless of the sentence actually imposed. ${ }^{15}$ To qualify as a "serious drug offense," for example, the statute criminalizing the offense must prescribe a "maximum term of imprisonment of ten years or more." ${ }^{\text {" }}$ A "violent felony" must be "punishable by imprisonment for a term exceeding one year." ${ }^{17}$ Importantly, "the sentences imposed are immaterial." 18

Because the sole measure of the offense's seriousness is the maximum term prescribed by law, some offenses that result in probation, low prison terms, or concurrent sentences will trigger the ACCA while some offenses that result in months or years of prison time will not. ${ }^{19}$ As a result, many dangerous criminals cannot be charged under the ACCA, while some relatively minor offenders can find themselves facing fifteen years to life.

\section{AMENDING THE ARMED CAREER CRIMINAL ACT TO RELY UPON THE SENTENCE IMPOSED}

This Comment proposes amending the Armed Career Criminal Act to redefine "serious drug offense[s]" and "violent felon[ies]" as offenses meeting other ACCA requirements "for which a term of imprisonment of $X$ months or more has been imposed," where $X$ would be some number of months. To avoid narrowing the ACCA's scope, $X$ would have to be lower than ten years for serious drug offenses and lower than one year for violent felonies. ${ }^{20}$

\footnotetext{
14. S. REP. NO. $97-585$, at 7 .

15. 18 U.S.C. $\$ 924(e)(2)$.

16. Id. $\$ 924(\mathrm{e})(2)(\mathrm{A})(\mathrm{i})$.

17. Id. $\$ 924(\mathrm{e})(2)(\mathrm{B})$.

18. S. REP. NO. $97-585$, at 9 .

19. Compare United States v. Speakman, 330 F.3d 1080 (8th Cir. 2003) (holding that three drug sales totaling less than a gram of methamphetamine over less than one month triggered the ACCA), with North Carolina v. Wilson, No. COA04-1120, 2005 WL 2649164, at *1 (N.C. Ct. App. Oct. 18, 2005) (punishing trafficking in 493.5 pounds of marijuana with thirty-five to forty-two months in prison, but holding that this would not constiture an ACCA predicate because the maximum penalty under North Carolina law was forty-two months).
}

20. The current ACCA applies to offenders convicted of crimes that have maximum sentences of ten years for serious drug offenses and one year for violent felonies. 18 U.S.C. 


\section{A. Matching Consequences with Culpability}

If the ACCA's application to an offender were based upon the imposed term rather than on the maximum sentence defined by statute for the crime, the ACCA would more accurately punish the most culpable offenders. To obtain a conviction, a prosecutor must prove only the legal elements of the crime. Those elements reflect state legislatures' judgments about the seriousness of a criminal offense in the abstract. But for any particular crime, a wide range of conduct may satisfy its statutory elements. Correspondingly, the culpability of offenders who commit the same statutory offense may vary. An Oregon college student caught selling two ounces of marijuana, for example, could be charged under the same state law that criminalizes trafficking in four tons of marijuana. ${ }^{21}$ As a result, the mere fact of a conviction often fails to reveal whether a particular defendant is a hardened criminal.

In comparison to the fact of conviction, the length of an offender's sentence is more correlated with his culpability, because sentencing proceedings often take into account more detailed information about the offender's conduct. For example, many states and the federal government determine the offender's base score for sentencing by reference to the general crime he committed, but then impose sentence enhancements based on factors such as the defendant's criminal history, whether the offense was committed with a deadly weapon, or whether the defendant's conduct was "sexually motivated."

$\$ 924(e)(2)(A)-(e)(2)(B)$. But far fewer offenders actually have sentences of those lengths imposed upon them. Instead, convicted criminals often are sentenced to community service, probation, or short prison terms. An offender found guilty in state court of a drug trafficking offense, for example, will receive an average of sixty months in prison or seven months in jail. See U.S. Dep'T OF Justice, State Court SentenCing OF CONVICTED Felons 2004-STATISTICAL TABLES (2007), available at http://www.ojp.usdoj.gov/bjs/pub/html/ scscfo4/tables/scso4103tab.htm. Thus, if the application of the ACCA relied upon an imposed sentence of ten years for serious drug offenses and one year for violent felonies, fewer criminals would be subject to the ACCA's penalties. This Comment does not take a firm position on the correct value of $X$. Amending the ACCA to rely upon the sentence imposed would not necessarily diminish the scope of the ACCA; that scope depends upon the value that Congress would choose for $X$.

21. See OR. Rev. STAT. $\$ 475.860$ (2007).

22. See, e.g., Adult SeNTENCING Guidelines MANUAL 2-26 (2007) (Washington), available at http://www.sgc.wa.gov/PUBS/Adult_Manual/Manual_2007_Section_III.pdf; MINNESOTA SENTENCING GUIDELINES AND COMMENTARY 2-24 (2008), available at http://www.msgc.state.mn.us/guidelines/guideo8.pdf; U.S. SENTENCING GUIDELINES MANUAL $\$ 1$ 1B1.4 (2007); WISCONSIN SENTENCING GUIDELINES NOTES 2-5, available at http://wsc.wi.gov/docview.asp?docid=3297. 
while a trial coarsely determines guilt or innocence, the sentencing phase more finely measures culpability and calibrates the sentence accordingly.

\section{B. Aligning the Armed Career Criminal Act with Deportation Standards and the Federal Sentencing Guidelines}

Our justice system already emphasizes the sentence imposed in other contexts. Under the Immigration and Nationality Act (INA), for example, a lawfully present alien is generally deportable if he has committed an "aggravated felony." ${ }^{23}$ The INA defines some (but not all) aggravated felonies, such as crimes of violence and theft offenses, by "the term of imprisonment." Courts have interpreted that phrase to refer to the sentence imposed rather than to the jail time the offender could have received. ${ }^{25}$

Similarly, the Federal Sentencing Guidelines use the sentence imposed when computing sentence enhancements based on prior criminal history. For example, defendants receive three criminal history points "for each prior adult sentence of imprisonment exceeding one year and one month imposed within fifteen years of the defendant's commencement of the instant offense." ${ }^{26}$ The Guidelines Manual makes clear that " $[t] o$ qualify as a sentence of imprisonment, the defendant must have actually served a period of imprisonment on such sentence." ${ }^{27}$ Unlike the ACCA, the Guidelines "equate the severity of the prior offense with the length of the sentence imposed for the previous conviction." 28

23. 8 U.S.C. $\$ 1101(a)$ (43) (listing and defining twenty-one categories of aggravated felonies).

24. Id. $\$ 1101(\mathrm{a})(43)(\mathrm{F})$ (defining "a crime of violence" under the statute as a violent crime meeting other statutory requirements "for which the term of imprisonment [is] at least one year"); id. $\$ 1101(\mathrm{a})(43)(\mathrm{G})$ (defining "a theft offense" under the statute as a theft meeting other statutory requirements "for which the term of imprisonment [is] at least one year").

25. See, e.g., Bovkun v. Ashcroft, 283 F.3d 166, 170 (3d Cir. 2002) ("We ... interpret this phrase to refer to the term of imprisonment that is actually imposed and not to the statutory minimum ....").

26. U.S. SENTENCING COMM'N, WORKSHEETS FOR INDIVIDUALS, at worksheet C (2008), available at http://www.ussc.gov/training/worksheets_0308.pdf.

27. U.S. SENTENCING GUIDELINES MANUAL $\$ 4$ A1.2 cmt. 2 (2007); see also id. $\$ 4 A_{1.2}$ (a)(1) ("The term 'prior sentence' means any sentence previously imposed upon adjudication of guilt ...." (emphasis added)).

28. Michael Edmund O'Neill, Abraham's Legacy: An Empirical Assessment of (Nearly) First-Time Offenders in the Federal System, 42 B.C. L. REV. 291, 304 (2001). 
The ACCA should employ the same framework that is applied in deportation proceedings and the Federal Sentencing Guidelines. ${ }^{29}$ In all three contexts, the justice system imposes consequences based on the offender's culpability and future dangerousness. Bringing all three areas into alignment would benefit prosecutors, judges, and defendants by making sentencing proceedings more consistent and predictable.

\section{Reducing Practical Difficulties}

Aligning the ACCA with immigration law and the Federal Sentencing Guidelines would reduce practical difficulties and simplify theoretical complexities that are built into the present system. The Supreme Court recently decided in Rodriquez $v$. United States that the "maximum term of imprisonment prescribed by law" must be computed with reference to state repeat offender laws in addition to the statute of conviction. ${ }^{30}$ Now, lawyers and federal judges must search through state statutes to find state recidivist laws that would increase the maximum sentence prescribed by law. These searches are particularly difficult when state recidivist enhancements have not already been applied; in those cases, judges must figure out whether the repeat offender statute could have made the defendant eligible for an enhanced term. That inquiry therefore requires federal courts to answer complicated, unsettled questions of state law and to resolve factual issues about crimes committed decades in the past.

Many state repeat offender statutes, for example, allow convictions in outof-state jurisdictions to count as predicate offenses if they are "substantially similar" to offenses that would count as predicates under the home state's laws. ${ }^{31}$ In People v. McGee, California courts had "to determine whether [a Nevada robbery] conviction ... qualifies as a conviction under [California law]." ${ }^{22}$ Answering that question required "a factual determination about [the]

29. This Comment should acknowledge, however, that at least one other federal statute, the Controlled Substances Act, employs a "maximum term of imprisonment" approach. See 21 U.S.C. $\$ 802$ (44) (defining a "felony drug offense" as an offense "that is punishable by imprisonment for more than one year under any law of the United States or of a State or foreign country"). While this Comment confines its argument to the ACCA, Congress might be wise to amend the Controlled Substances Act to achieve greater uniformity in the sentencing system.

30. 128 S. Ct. 1783,1786 (2008).

31. See, e.g., 730 Ill. Comp. Stat. AnN. 5/5-5-3.2(b)(1) (West 2007); N.C. Gen. Stat. AnN. \15A-1340.14(e) (West 2007); TENN. CODE ANN. $\$ 40-35-107(b)(5)$ (West 2003).

32. 133 P.3d 1054, 1062 (Cal. 2006). 
criminal defendant's intent," ${ }^{33}$ which could only be made after a thorough review of the record-a difficult task even for a state court. After Rodriquez, such questions must be resolved by federal courts as a matter of first impression.

Relying upon the sentence imposed to calculate ACCA sentence enhancements would make the search for state recidivist laws unnecessary. In trials ending with a jury verdict, the imposed sentence is readily available from basic court documents. In Wisconsin, for example, judges simply fill in the blank space on a standard form that reads: "IT IS ADJUDGED that the defendant is guilty as convicted and ... is sentenced to prison for .34 Similarly, court forms in the State of Washington contain the sentence length on their face. ${ }^{35}$ Plea bargaining agreements also clearly report the sentence length. ${ }^{36}$ Thus, if the application of the ACCA was based upon the sentence imposed instead of the maximum sentence prescribed by law, complex searches through state statute books and inquiries into the facts of crimes committed years ago would be replaced by a simple glance at the record.

Because using the sentence imposed would simplify the court's task, it does not implicate the concerns expressed by the Supreme Court's decision in Taylor $v$. United States. ${ }^{37}$ In Taylor, fearing a quagmire of "evidentiary disputes" and "collateral trials," the Court refused to allow federal courts to look beyond the fact of conviction and the statute defining the prior offense when applying the ACCA..$^{38}$ To preserve scarce judicial resources, courts are generally prohibited from looking to the underlying trial record; the statutory text must be treated as conclusive. ${ }^{39}$ But Taylor's concerns with judicial economy are not applicable here. In this context, using the imposed prison term would promote judicial economy by avoiding the type of evidentiary disputes about which the Taylor Court was concerned. ${ }^{40}$

33. People v. McGee, 9 Cal. Rptr. 3d 586, 597 (Ct. App. 2004).

34. STATE OF WIS., JUDGMENT OF CONVICTION AND SENTENCE (2007), available at http://www.wicourts.gov/forms/CR-212.pdf.

35. See, e.g., SUPERIOR COURT OF WASH., JUdGMENT AND SENTENCE $\$ 4.5$ (2000), available at http://www.jin.wa.gov/standards/justiceCommonArchitecture/appendixc.doc.

36. See, e.g., Rules of the Court of Criminal Appeals of Okla., Uniform Plea of Guilty, PART B: SENTENCE ON PLEA 9 (2008), available at http://www.occa.state.ok.us/ forms/Form\%2013.10.doc.

37. 495 U.S. 575 (1990).

38. Shepard v. United States, 544 U.S. 13, 23 (2005) (discussing Taylor, 495 U.S. at 601).

39. Taylor, 495 U.S. at 601-02.

40. Supreme Court case law carves out a much-criticized exception to the Sixth Amendment's trial by jury requirement for the fact of a prior conviction. See Almendarez-Torres v. United 


\section{SENTENCING DISPARITIES: A DRAWBACK OF RELYING UPON THE SENTENCE IMPOSED}

Despite the advantages of the approach discussed above, this Comment's recommendation could cause the ACCA to magnify disparities already inherent in sentencing. Studies have shown that race, gender, and age, among other arbitrary factors, are correlated with sentence length. ${ }^{41}$ Amending the ACCA to rely upon sentencing decisions that exhibit these disparities might simply replace one evil with another.

Many racial or other disparities in sentencing, however, may be the product of bias that was present only at the trial phase. ${ }^{42}$ In such cases, those disparities will exist regardless of whether the ACCA uses the sentence imposed or the statutory maximum, because both the fact of a defendant's conviction for a crime with a particular statutory maximum and his resulting sentence may have been influenced by the biased trial. Furthermore, in recent years, state and federal justice systems have increasingly used sentencing guidelines to constrain judicial discretion, ${ }^{43}$ making it more difficult for bias to infiltrate sentencing. Indeed, state sentencing guidelines "are popular because they have proven more effective than alternative sentencing regimes as a means to promote consistency and fairness." 44 A recent report on sentencing concluded that " $t]$ he track record of state guideline systems in the domain of race and sentencing has been one of marginal but apparently positive effects." ${ }^{\text {s5 }}$ Basing

States, 523 U.S. 224 (1998). If that case is overruled, this Comment's recommendation would not be affected; the question of the length of the imposed term would merely have to be submitted to a jury rather than to a judge.

41. See, e.g., Comm. on Racial and Gender Bias in the Justice Sys., Final Report of the Pennsylvania Supreme Court Committee on Racial and Gender Bias in the Justice SYSTEM 125-62 (2003), available at http://www.courts.state.pa.us/INDEX/supreme/ BiasCmte/ FinalReport.ch1.pdf.

42. See, e.g., Rachel E. Barkow, Recharging the Jury: The Criminal Jury's Constitutional Role in an Era of Mandatory Sentencing, 152 U. PA. L. REV. 33, 74-75 (2003) (discussing jury racial bias).

43. See id. at 34; see also U.S. SENTENCING COMM'N, FINAL REPORT ON THE IMPACT OF UNITED STATES v. BOOKER ON FEDERAL SENTENCING 106-09 (2006) (concluding that although "demographic factors are associated with sentence length ... their contribution to sentence lengths before and after Booker are identical"), available at http://www.ussc.gov/ booker_report/Booker_Report.pdf.

44. Richard S. Frase, State Sentencing Guidelines: Diversity, Consensus, and Unresolved Policy Issues, 105 COLUM. L. REV. 1190, 1192 (2005).

45. Kevin R. Reitz, American Law Institute, Model Penal Code: Sentencing, Plan for Revision, 6 Buff. Crum. L. Rev. 525, 586 (2002). 
the application of the ACCA upon the imposed sentence would be a vote of confidence for these improving state sentencing regimes. ${ }^{46}$

\section{IMPLICATIONS FOR THE ROLES OF PROSECUTORS AND JUDGES}

Basing the application of the ACCA upon the sentence imposed would affect the plea bargaining relationship between prosecutors and defendants even before the defendant is charged under the ACCA. This effect would most likely magnify the role of judges and reduce prosecutorial power during plea bargaining. The current version of the ACCA encourages defendants to plead guilty to a lesser offense with a lower maximum prison term. Prosecutors enjoy unreviewable discretion when choosing which charges to pursue. ${ }^{47}$ Thus the ACCA's current structure strengthens the prosecutor's role by allowing him to threaten a defendant with an ACCA-predicate conviction. Using the sentence imposed, on the other hand, would refocus the bargaining (at the margins) on the actual prison term rather than on the charged offense itself. This change would transfer some power from prosecutors to judges, who have more control over sentences imposed.

To be sure, the prosecutor's initial charging decision will continue to play an important role in determining the sentence imposed due to the existence of sentencing guidelines that limit judicial discretion, among other factors ${ }^{48} \mathrm{But}$ in the wake of the Supreme Court's decision in Blakely $\nu$. Washington ${ }^{49}$ which weakened mandatory state sentencing regimes, state judges retain substantial sentencing discretion. If the ACCA is amended to use the sentence imposed, state judges will likely play a more important role in determining which offenders can be charged under the ACCA.

46. Recent Supreme Court decisions have made clear that the Sixth Amendment trial by jury requirement applies to state and federal sentencing guidelines. See United States v. Booker, 543 U.S. 220 (2005); Blakely v. Washington, 542 U.S. 296 (2004). To some degree, those holdings obstruct the guidelines' goal of reducing sentencing disparities.

47. See Craig S. Lerner, Conspirators' Privilege and Innocents' Refuge: A New Approach to Joint Defense Agreements, 77 NOTRE DAME L. ReV. 1449, 1460 (2002).

48. Id. State sentencing guidelines, however, are more flexible than the Federal Sentencing Guidelines, which "try to structure and define every single decision." Richard S. Frase, Is Guided Discretion Sufficient? Overview of State Sentencing Guidelines, 44 ST. Louls U. L.J. 425, 426 (2000). State judges, therefore, retain greater discretion than federal judges to influence the sentence imposed. See GeORGe Fisher, Plea Bargaining's TriumPH 210-12 (2003).

49. 542 U.S. 296. 
While the issues raised by altering the balance of power between prosecutors and judges are complex, ${ }^{50}$ this Comment cautiously suggests that a shift of power from prosecutors to judges at the margins is desirable. Prosecutors' charging decisions are not regulated by statute $;{ }^{51}$ by contrast, state judges rely on sentencing commissions that include "judges, prosecutors, defense attorneys, correctional officials, public members, and sometimes legislators." ${ }^{52}$ The composition of these sentencing commissions may provide some democratic legitimacy to a judge's sentencing decisions. ${ }^{53}$ Moreover, shifting power from prosecutors to judges would promote transparency. While plea bargains often are negotiated in a back room hidden from public view, a judge's sentencing decision is handed down in open court.

\section{CONCLUSION}

The Armed Career Criminal Act does not adequately distinguish hard-core, repeat criminals from relatively minor offenders. By focusing on the maximum term of imprisonment prescribed by law for prior offenses rather than on the actual sentence imposed, the ACCA allows many dangerous, recidivist criminals to escape its grasp and tolerates inequitable sentencing decisions. Amending the ACCA to rely on the actual term imposed would ensure that the most hardened offenders receive the longest sentences, bring the ACCA into line with deportation standards in immigration law and with the Federal Sentencing Guidelines, and simplify the work of prosecutors, judges, and defense lawyers.

\section{ETHAN DAVIS}

\footnotetext{
50. For a thorough discussion of some of these issues, see FISHER, supra note 48 , at 205-30.

51. See Bordenkircher v. Hayes, 434 U.S. 357,364 (1978).

52. Frase, supra note 44 , at 1197.

53. To be sure, state prosecutors are often democratically elected officials while not all state judges are elected. See Carol S. Steiker, Death, Taxes, and-Punishment? A Response to Braithwaite and Tonry, 46 UCLA L. REV. 1793, 1798 (1999).
} 